\author{
Aneta Nisiobęcka \\ Archiwum Instytutu Pamięci Narodowej
}

\title{
NIEPOŻĄDANI - FRANCJA WOBEC EMIGRACJI POLSKIEJ W LATACH 1930-1944
}

\author{
Abstract \\ UNDESIRABLE - FRENCH ATTITUDES TOWARDS POLISH \\ IMMIGRATION IN THE YEARS 1930-1944
}

Polish historical literature referring to migrations to France is dominated by issues of emigrants' everyday life and activities. The issue of politics and the legal approach of the French state towards migrants has been hitherto treated marginally. This article discusses the topic of Polish migrants adapting to their new situation and living in France through the perspective of decrees and circulars of the French state regulating the status of migrants.

Sources from the French archives indicate that France tightened their laws concerning immigrants in 1930s, including allowing for the establishment of internment camps for "undesirable" foreigners.

Key words: work migration, Polish-French convention, internment camps, expulsions Słowa kluczowe: emigracja zarobkowa, konwencja polsko-francuska, obozy internowania, ekspulsje

Badacze zajmujący się problematyką historii polskiej emigracji politycznej i zarobkowej we Francji w swoich badaniach podejmowali przede wszystkim kwestie dotyczące życia i działalności społeczności polskiej we Francji ${ }^{1}$. Poza obszarem badawczym pozosta-

1 Patrz m.in. A. Paczkowski, Prasa i społecznośćpolska we Francii 1920-1940, Wrocław-Warszawa-KrakówGdańsk 1979; J. Mond, Towaryystwo Historyczno-Literackie i Biblioteka Polska w Paryżu. Historia i dzień dzisiejssy, „Nauka Polska” 1991, z. 2, s. 93-116; R. D zwonkow ski, W. Śla dkow ski, Polonia francuska, [w:] Polonia w Europie, red. B. Szydłowska-Cegłowa, Poznań 1992, s. 365-410; E. Gogolewski, Szkolnictwo polskie we Francji (1833-1990), Wrocław 1998; G. Garçon, Les relations entre l'Union des Associations Catholiques Polonaises et L'Union Centrale des Polonais 1945-1949, „Revue du Nord” 1992, no 7, 
wiali zaś sprawę polityki państwa francuskiego i jego prawodawstwa wobec imigrantów osiedlających się w jego granicach. W artykule tym podejmę temat adaptacji i życia polskiej społeczności we Francji, przyjmując za punkt wyjścia dekrety i okólniki państwa francuskiego regulujące pobyt cudzoziemców we Francji.

Materiał źródłowy z archiwów departamentalnych we Francji: Archives Départementales de l'Ariège we Foix, Archives Départementales des Pyrénées-Atlantiques w Pau, Archives des Pyrénées-Orientales w Perpignan, Archives Départementales du Pas-de-Calais w Arras-Dainville oraz z Archives Ministère des affaires étrangères w Paryżu dowodzi, że Francja w wyniku zmieniającej się sytuacji gospodarczej i międzynarodowej bezwzględnie zaostrzała przychylne wcześniej cudzoziemcom prawodawstwo oraz usankcjonowała w 1938 r. na swoim terytorium obozy odosobnienia dla „niepożądanych" obcokrajowców, które następnie zostały przekształcone przez państwo Vichy w „ośrodki zakwaterowania” oraz obozy koncentracyjne z przeznaczeniem m.in. dla cudzoziemskich Żydów.

Dokumentacja dotycząca obozów jest zachowana prawie w całości, duża jej część stanowią dossier obcokrajowców (w tym również Polaków), ułożone alfabetycznie. Oprócz dokumentów osobowych obywateli polskich archiwa zawierają obfity materiał źródłowy na temat organizacji obozów, raporty szefów obozu z informacjami na temat liczby osób tam przebywających oraz przydzielanych im racji żywnościowych. Zachowana jest także dokumentacja dotycząca działalności organizacji charytatywnych niosących pomoc osobom internowanym, wizyt w obozach przedstawicieli m.in. Polskiego Czerwonego Krzyża - PCK, a po jego delegalizacji w 1941 r. przez władze Vichy Towarzystwa Opieki nad Polakami we Francji (Groupement d'Assistance aux Polonais en France - TOPF), Chrześcijańskiego Stowarzyszenia Młodzieży Męskiej we Francji (L'Union Chrétienne des Jeunes Gens en France - YMCA), stowarzyszenia Les Amis de la Pologne. Materiały te mogą być interesującym uzupełnieniem archiwaliów przechowywanych w Bibliotece Polskiej w Paryżu, w tym takich spuścizn jak: Konsulat Polski w Tuluzie, Towarzystwo Opieki nad Polakami we Francji czy stowarzyszenia Les Amis de la Pologne i jego fundatorki Rosy Bailly.

Jest faktem, że po zakończeniu Wielkiej Wojny kraj nad Sekwaną stał się dla wielu obcokrajowców terre d'accueil. Jednakże powodem, dla którego chętnie otworzył on swoje granice, były jego straty demograficzne i gospodarcze po I wojnie światowej, w czasie której Francja straciła 3 mln obywateli, z czego 40 proc. zabitych stanowili rolnicy, a 25 proc. robotnicy przemysłowi. Wojna spowodowała również znaczne osłabienie najbar-

hors-série, Collection Histoire, Université de Lille III, s. 35-47; J. Michel, Aux origines de la presse polonaise du Nord-Pas-de-Calais: Le transfert de Westphalie après la première guerre mondiale, „La presse polonaise en France. Polska prasa we Francji 1918-1984”, textes réunis par D. Beauvois, „Revue du Nord” 1988, no 4, hors-série, Collection Histoire, Université de Lille III, s. 45-59. 
dziej rozwiniętych przemysłowo regionów w północno-wschodniej Francji². Odbudowę gospodarki francuskiej mogło zagwarantować sprowadzenie imigrantów. Kraje sąsiadujące z Francją nie były w stanie dostarczyć wykwalifikowanej siły roboczej, dlatego też Francuzi zwrócili uwagę na państwa Europy Środkowo-Wschodniej, w tym m.in. na restytuowaną Polskę, która z kolei w emigracji swoich obywateli do Francji widziała rozwiązanie problemu przeludnienia i bezrobocia. Francja zaś dzięki imigrantom z Polski mogła zyskać potrzebnych jej do odbudowy kraju robotników rolnych i górników³. Z tych powodów w okresie międzywojennym Francja stała się głównym krajem imigracyjnym w Europie, a Polska - emigracyjnym ${ }^{4}$.

Po kilkumiesięcznych negocjacjach 3 września 1919 r. rządy polski i francuski podpisały konwencję polsko-francuską o emigracji i imigracji, która gwarantowała m.in. równość płac, obowiązkowe kontrakty o pracę dla robotników przybywających w ramach konwencji, zapewnienie ochrony praw socjalnych robotników w razie wypadku przy pracy. Konwencja zezwalała na funkcjonowanie we Francji polskich instytucji opiekujących się polskimi robotnikami oraz regulowała również zapisy dotyczące emigracji indywidualnej $j^{5}$.

Rok później, 5 czerwca 1920 r., rząd polski podpisał umowę z Francją zezwalająca Polakom zamieszkującym tereny Nadrenii i Westfalii na emigrację do Francji (Polska ze względu na trudną sytuację gospodarczą nie mogła ich przyjąć), która była konsekwencją zapisów w artykule 91. traktatu wersalskiego, stanowiącym o wyborze obywatelstwa polskiego bądź niemieckiego przez Polaków zamieszkujących terytorium niemieckie. Ci, którzy opowiedzieli się za wyborem polskiego obywatelstwa, musieli opuścić terytorium Niemiec. Emigracja „westfalacka”, bo tak ją się określa, była przede wszystkim emigracja górniczą ${ }^{6}$.

2 A. Taront, Wspomnienia emigranta polskiego zpótnocnej Francji, do druku przygotowali i komentarzami opatrzyli: D. Beauvois, K. Ożóg, J. Śrutek, Wrocław-Warszawa-Kraków, 1994, s. 87-88. Jean Jacques Becker i Serge Berstein podaja, że Francja wśród $3 \mathrm{mln}$ osób straciła 1,5 $\mathrm{mln}$ żołnierzy. Straty ludnościowe zrekompensowało przyłączenie Alzacji i Lotaryngii, na terenach których zamieszkiwało 1,9 mln osób. W wyniku działań wojennych zdewastowanych zostało 10 departamentów francuskich, ok. 11 tys. budynków publicznych, 350 tys. domów, 62 tys. kilometrów dróg, 5 tys. dróg kolejowych, a blisko $3 \mathrm{mln}$ ha rolnych nie nadawało się do zagospodarowania. J.J. Becker, S. Berstein, Victoire et frustrations, 1914-1929, Nouvelle bistoire de la France contemporaine, vol. 12, Paris 1990. s. 148-152.

3 J.J. Becker, S. Berstein, op. cit., s. 161-163; H. Ja now ska, Polska emigracja zarobkowa we Francji, 19191939, Warszawa 1964, s. 59-60.

4 Ibidem, s. 58-60; A. Taront, op. cit., s. 87-88.

5 J. Ponty, Polonais méconnus. Histoire des travailleurs immigrés en France dans l'entre-deux-guerres, Paris 1988, s. 47-48; Tekst konwencji polsko-francuskiej o emigracji w: J. Pon ty, L'immigration dans les textes. France, 1789-2002, Belin, Paris 2004, s. 124-125.

6 J. Gruszyński, Społecznośćcolska we Francji. Problemy integracii trzech pokoleń, 1918-1978, Warszawa 1981, s. 37; H. Ja now sk a, Polska emigracja zarobkowa..., s. 103. 
Według spisu ludności w 1921 r. liczba Polaków wynosiła ok. 46 tys. obywateli, co oznaczało, że stanowili oni siódmą co do wielkości grupę emigrantów we Francji. Pięć lat później polska emigracja została sklasyfikowana na trzecim miejscu zaraz po emigrantach z Włoch, Belgii i Hiszpanii, a na początku lat 30. Polacy znaleźli się na drugim miejscu. Od 1921 do 1931 r. liczba polskiej emigracji zwiększyła się prawie jedenastokrotnie i wynosiła ponad 500 tys. osób 7 .

Największe skupiska Polaków były w regionie północnym Nord-Pas-de-Calais. W departamentach Nord i Pas-de-Calais zamieszkiwała jedna trzecia polskiej emigracji. Drugim co do liczebności Polaków we Francji był region paryski (miasto Paryż, departamenty Seine-et-Marne, Yvelines, Essone, Hauts-de-Seine, Seine-Saint-Denis, Val-de-Marne, Val-d'Oise). Na trzecim miejscu (10-15 proc. polskiej społeczności) sklasyfikowany został region alzacko-lotaryński z departamentami: Moselle, Meurthe-et-Moselle, Meuse oraz Haut-Rhin. Czwarte miejsce zajmował region pikardyjsko-szampański, gdzie osiedliło się około 10 proc. polskich robotników rolnych. Inne większe skupiska Polaków rozmieszczone były na południu Francji w regionie Saint-Etienne. Ponadto w innych departamentach istniały również mniejsze skupiska emigracji polskiej, zarówno górniczej, jak i rolniczej, np. w departamentach Tarn i Tarn-et-Garonne, Haute-Garonne, Lot-et-Garonne ${ }^{8}$.

W związku z napływem obcokrajowców państwo francuskie w latach 20. ubiegłego wieku wydało kilka ustaw i dekretów regulujących ich pobyt na terenie Francji. Ustawy te dotyczyły wydawania dowodów osobistych, kart tożsamości dla robotników i górników przybywających do Francji, opłat za ich wydawanie oraz ubiegania się o nabycie obywatelstwa francuskiego?.

Z pewnością stabilizację cudzoziemcom przynosiło przyjęcie obywatelstwa francuskiego. Ustawa z 10 sierpnia 1927 r. zezwalała na ubieganie się o jego nabycie po trzech latach zamieszkiwania we Francji. Wcześniej, na mocy ustawy z 26 czerwca 1889 r., cudzoziemcy mogli o nie wystapić po 10 latach przebywania w kraju. Obywatelstwo można było nabyć już od 18., a nie jak poprzednio od 21. roku życia. Ponadto ustawa stanowiła, że kobieta, która poślubiła obcokrajowca, mogła zachować swoje obywatelstwo, a emi-

\footnotetext{
J. Gruszyński, op. cit., s. 57.
}

8 Ibidem, s. 64-65; H. Ja now sk a, Polska emigracja zarobkowa..., s. 123-127; J. Ponty, Polonais méconnus..., s. $118-131$.

9 O prawodawstwie francuskim wobec imigrantów w latach 20. XX w. czytaj m.in.: H. Ja now ska, Polska emigracja zarobkowa..., s. 161-162; J. Ponty, Polonais méconnus..., s. 106-109; ea de m, L'immigration dans les textes..., s. 139-143; A. Nisiob ęck a, Polacy w oboz̨ie Gurs 1939-1945, „Studium Migracyjne - Przegląd Polonijny" 2011, z. 3, s. 9-10; Archives Ministère des Affaires Étrangères [dalej cyt.: AMAE], Série C, Administrative 1908-1940, sygn. 265, Verification, Séjour et expulsion. 
grantka poślubiająca Francuza nabywała obywatelstwo francuskie w dniu ślubu. Dzieci ze związków mieszanych również nabywały automatycznie obywatelstwo francuskie ${ }^{10}$.

Nie ulega wątpliwości, że rząd francuski, wydając tak przychylną ustawę o naturalizacji (tzn. przyjęciu obywatelstwa), chciał związać obcokrajowców z Francja. Pomimo tej przychylności Polacy aż do połowy lat 30. niechętnie starali się o naturalizację. Pierwszą i podstawowa przyczyną odmowy przyjęcia obywatelstwa była myśl o powrocie do Polski11. Od 1920 do 1930 r. tylko 4 proc. Polaków zdecydowało się na przyjęcie obywatelstwa i w większości byli to górnicy i robotnicy przemysłowi. Zmianę stanowiska w sprawie naturalizacji przyniósł kryzys gospodarczy we Francji, gdyż przyjęcie obywatelstwa francuskiego chroniło przed utratą pracy, ponadto gwarantowało również stabilizację materialną we Francji ${ }^{12}$.

\section{Indésirables en France - zmiana polityki francuskiej względem cudzoziemców w czasie kryzysu gospodarczego}

Na początku lat 30. XX wieku liczba obcokrajowców we Francji wynosiła ok. 3 mln, co stanowiło 7 proc. jej ludności. Ich położenie uległo radykalnej zmianie w czasie kryzysu ekonomicznego. Stawali się oni dla francuskich władz indésirables, tzn. niepożądani. Według rządu francuskiego walkę z kryzysem można było wygrać poprzez ,pozbycie się" imigrantów, a ograniczenie ich zatrudnienia chroniło francuski rynek pracy. Podczas debaty parlamentarnej w 1934 r. dotyczacej sytuacji we francuskim górnictwie oraz ekspulsji polskich górników premier Francji Pierre Étienne Flandin powiedział: „Jest rzeczą zupełnie normalna poproszenie cudzoziemskich robotników, aby powrócili do swoich krajów, skoro górnik francuski jest bezrobotny"13.

Przy redukcji zatrudnienia obcokrajowcy byli pierwsi do zwolnienia, a przy zatrudnianiu władze francuskie popierały przyjmowanie do pracy w pierwszej kolejności

10 Journal Officiel (dalej: J.O.) z 14 VIII 1927 r., s. 8697-8699, cyt za: Indésirables en France 1938-1942. Dossier pédagogique no 7 par S. Orsoni, professeur du Service éducatif des Archives départementales des Bouches-du-Rhône, 2003, 1a, 1b; J. Ponty, Polonais méconnus..., s. 244 . W 1931 r. naturalizowani Polacy stanowili 13,5 tys. osób, tj. 3,8 proc. ogółu naturalizowanych cudzoziemców. W 1933 r. liczba Polaków, którzy przyjęli francuskie obywatelstwo, wzrosła do 30 tys. i stanowiła 9 proc. ogółu naturalizowanych cudzoziemców. S. Ja ros, Reemigracja Polaków z Francji w latach 1946-1948, „Problemy Polonii Zagranicznej" 1971, t. 6/7, s. 68; AMAE, Série C, Administrative 1908-1940, sygn. 265, Note A.S. de la naturalisation, le 25 X 1938, k. 113-116. Tekst ustawy można znaleźć w: J. Ponty, L'immigration dans les textes..., s. 153-158.

11 A. Taront, op. cit., s. 97.

12 J. Gruszyński, op. cit., s. 217.

13 H. Janow ska, Polska emigracja zarobkowa..., s. 170. 
obywateli francuskich. Wrogi stosunek do obcokrajowców podsycały jeszcze artykuły w prasie prawicowej i skrajnie prawicowej ${ }^{14}$. Największe bezrobocie wśród cudzoziemców przypadło na lata 1932-1934. Francja zanotowała wtedy 360 tys. bezrobotnych. Bezrobocie dotknęło wszystkie gałęzie przemysłu, górnictwo, przemysł metalowy oraz metalurgiczny, nie ominęło gospodarstw rolnych. Częściowe bezrobocie ${ }^{15}$ dotknęło robotników każdej narodowości, nawet Francuzów, natomiast całkowite bezrobocie - tylko cudzoziemców ${ }^{16}$. Dla nich rozpoczął się ciężki okres, każdy dzień był dniem walki o przetrwanie. Zarobione $z$ trudem oszczędności w każdym polskim domu powoli się wyczerpywały. Robotnicy, szukając dodatkowych źródeł dochodu, zajęli się przemytem. Dla wielu z nich proceder ten zakończył się ekspulsją ${ }^{17}$.

Podstawę prawną dla przedsiębiorstw zatrudniających emigrantów stanowił dekret z 10 sierpnia 1932 r. Zobowiązywał on francuską administrację do wydawania rozporządzeń wykonawczych określających odsetek cudzoziemców, jaki w danym regionie i w danej dziedzinie przemysłu mógł być zatrudniony. Wszelkie nadwyżki, tj. od 5 do 10 proc., podlegały zwolnieniu. Do tego na mocy wcześniejszego dekretu z 22 maja 1932 r. poszukiwanie pracy i zmiana zawodu wymagały zezwolenia władz departamentalnych.

W 1934 r. minister spraw wewnętrznych w rządzie Gastona Doumergue'a Albert Sarraut zapoczątkował „systematyczną akcję wypędzania z kraju elementów niepożądanych”. Władze francuskie w celu ,pozbycia się” emigrantów wykorzystywały instrukcję ministerialną z 31 marca 1934 r. o udzielaniu bezpłatnych sześciomiesięcznych urlopów wraz z pokryciem kosztów powrotu do kraju. W rzeczywistości kryzysu ekonomicznego we francuskich kopalniach urlopy z sześciomiesięcznych zamieniły się na bezterminowe. Górnik, mając do wyboru opuszczenie kraju na koszt kopalni lub na koszt własny, wybierał „dobrowolnie” taki bezterminowy urlop. Jeżeli odmówił - natychmiast otrzymywał wymówienie z pracy. Wprawdzie w wielu przypadkach kopalnie traciły wykwalifikowaną siłę robocza, jednakże naciski na redukcję zatrudnienia wśród cudzoziemców wychodziły jednoznacznie od kół rządowych, a nie ze strony przedsiębiorstw kopalnianych $^{18}$. Już w 1933 r. pisano we francuskiej prasie, że masowe zwolnienia cudzoziemców nie poprawiają wcale sytuacji na rynku pracy, gdyż Francuzi nie zamierzaja pracować w określonych zawodach ${ }^{19}$.

\footnotetext{
14 J. Ponty, Polonais méconnus..., s. 287-288.

15 Częściowo bezrobotni stanowili około 50 proc. zatrudnionych, nie wliczając w tę liczbę robotników rolnych. H. Ja now ska, Polska emigracja zarobkowa..., s. 165-166.

16 Ibidem.

17 W. Markiewicz, Prz̧eobrażenia śmiadomości narodowej reemigrantów polskich z Francji, Poznań 1960, s. 98.

18 H. Ja now ska, Polska emigracja zarobkowa..., s. 169, 173; W. Markiewicz, op. cit., s. 98.

19 H. Janow ska, Polska emigracja zarobkowa..., s. 173-174.
} 
Nie przekonywało to jednak władz rządowych Francji, które następnymi dekretami ograniczały swobodę przemieszczania się robotników cudzoziemskich. Na mocy dekretu z 6 lutego 1935 r. dowód tożsamości wydawany dla cudzoziemców był ważny jedynie na terenie departamentu, w którym oni zamieszkiwali. Artykuł 4. tego dekretu wymagał zgłoszenia każdej zmiany miejsca zamieszkania do prefekta departamentu. W przypadku utraty pracy przez robotników dekret ten uniemożliwiał znalezienie nowego zatrudnienia na terenie innego departamentu i wymuszał na nich szukanie pracy w granicach jednego departamentu. Co więcej, dekret ten nie zezwalał na odnawianie kart tożsamości cudzoziemcom, którzy przybyli do Francji po 1925 r., a przedłużenie ważności karty tożsamości uzależniał od zapewnienia władz prefekturalnych, czy cudzoziemiec cieszy się „dostatecznym zaufaniem” lokalnej społeczności francuskiej. Wejście w życie tego dekretu „pozwoliło”, według słów ówczesnego ministra pracy Paula Jacquiera, na „dobrowolne” opuszczenie Francji przez obcokrajowców. Tuż po wejściu w życie tego dekretu na początku 1935 r. urzędy francuskie zanotowały 10,8 tys. „dobrowolnych wyjazdów”. Problemów z odnowieniem karty tożsamości nie mieli ci cudzoziemcy, którzy byli w związkach małżeńskich z obywatelami francuskimi lub wystąili o nadanie obywatelstwa francuskiego swoim dzieciom. W rzeczywistości kryzysu gospodarczego prawie 30 proc. próśb o odnowienie karty tożsamości rozpatrywano negatywnie ${ }^{20}$.

Nie ulega wątpliwości, że lokalne władze francuskie z gorliwością realizowały wytyczne kół rządowych w odniesieniu do obcokrajowców, celowały w szykanowaniu cudzoziemców oraz nadużywały nakazu ekspulsji pod byle pretekstem. Strach przed ekspulsją wśród emigracji polskiej był uzasadniony. Z Francji wydalano Polaków z powodu błahych przewin: nieobecności w pracy, zarejestrowania w kartotekach sądowych na skutek drobnych wykroczeń. Nawet chwilowy brak pracy stawał się podstawą oskarżenia o włóczęgostwo, a tym samym był to już dostateczny powód do wydalenia z Francji.

Oprócz władz państwowych, które przestały być „przyjazne” robotnikom cudzoziemskim, wrogą postawę wobec cudzoziemców w okresie kryzysu okazywali również sami Francuzi. Uważali, że duży napływ obcokrajowców (invasion des étrangers) był główną przyczyną bezrobocia: ,Jeżeli Francja cierpi z powodu bezrobocia, to tylko z powodu tych dwóch milionów obcokrajowców znajdujących się w kraju”21. W górnictwie uznawali oni za rzecz normalną, że to właśnie Polacy powinni być w pierwszej kolejności pozbawiani pracy. Nazywali Polaków intruzami, zjadaczami chleba. Argumentowali to

20 J. Ponty, Polonais méconnus..., s. 291, 303-304; e a de m, L'immigration dans les textes..., s. 190-193,196198; Halina Janowska w swoim artykule, pisząc o dekrecie zezwalającym zatrudniać odpowiednią liczbę cudzoziemców, błędnie podaje datę 10 VII 1932 r. H. Ja nowska, Dwie reemigracje Polaków ₹. Francji, „Problemy Polonii Zagranicznej” 1964-1965, t. 4, s. 12, 14; ea dem, Polska emigracja Zarobkowa..., s. 166168; P. Weil, La France et ses étrangers. L'aventure d'une politique de l'immigration de 1938 à nos jours, 1991 et 2004, s. 29.

21 H. Janow ska, Polska emigracja zarobkowa..., s. 214. 
słowami: „Oni jedzą nasz chleb” (Ils mangent notre pain), „Niech wracają do siebie” (Qu'ils repartent chez eux), „Jazda do Polski” (Va-t-en en Pologne). Rzadkością było, aby słowo „Polak” wymawiane przez Francuza nie zawierało tonu poniżającego. Przeciętny Francuz widział w Polaku „wyzyskiwacza”, który przybył do Francji w celu dorobienia się ich kosztem ${ }^{22}$. W dobie kryzysu ekonomicznego bardzo rzadko pojawiały się głosy w obronie emigracji polskiej mówiące o ogromnej roli polskiego robotnika i górnika, dzięki którym Francja wydźwignęła się ze zniszczeń wojennych ${ }^{23}$.

Jednym ze sposobów uniknięcia utraty pracy oraz ekspulsji z Francji było przyjęcie obywatelstwa francuskiego. Liczba naturalizowanych Polaków w 1931 r. wynosiła 13,5 tys. osób, a cztery lata później prawie się podwoiła dochodząc do 26,2 tys. osób. Przed wybuchem wojny liczba Polaków, którzy przyjęli obywatelstwo francuskie, osiągnęła stan 29 tys. osób ${ }^{24}$. Od stycznia do marca 1939 r. 995 Polaków przyjęło obywatelstwo francuskie, z czego 418 naturalizowało się w styczniu $1939 \mathrm{r}^{25}$ Analizując statystyki Polaków naturalizowanych w okresie kryzysu i tuż po nim, widać jasno, że zwiększenie liczby podań o naturalizację nastąpiło w pierwszej połowie lat 30., o zmianie stanowiska polskiej emigracji w kwestii naturalizacji zadecydował w dużym stopniu czynnik ekonomiczny.

Od 1933 do 1936 r. z departamentu Pas-de-Calais nakaz opuszczenia Francji otrzymało 7687 polskich górników oraz 11235 kobiet i dzieci, natomiast w okresie kryzysu ekonomicznego z całego terytorium Francji wydalono 117 tys. osób ${ }^{26}$. Jedna z najbardziej znanych i często wspominanych w literaturze przedmiotu fali ekspulsji (97 Polaków) nastapiła w 1934 r. po strajku w kopalniach Escarpelles, w którym uczestniczyli Polacy z Leforest ${ }^{27}$.

W 1931 r. we Francji polska społeczność liczyła 507811 osób. Spis sporządzony 5 lat później wykazał liczbę Polaków zmniejszoną o blisko 17 proc. Część Polaków w wyniku trwającego kryzysu ekonomicznego zdecydowała się na powrót do kraju. Według danych Ministerstwa Pracy Francji w latach 1931-1936 kraj nad Sekwaną opuściło 129819

22 J. Ponty, Dépasser les stéréotypes: au sujet de l'immigration polonaise en France, [w:] La France, la Pologne audélà des stéréotypes, textes réunis par M. Delaperrière, J. Doberszyc, B. Drwęski, Paris 2004, s. 30; J. Gruszyński, op. cit., s. 106, 144.

23 E. Gogolewski, Obrona robotnikón polskich we Francji i zwiazki zawodowe w okresie miedsynojennym, [w:] Organizacje polonijne w Europie Zachodniej, wspótczesność i tradycja. Materialy z konferencji naukowej w dniach 2 i 3 kwietnia 1987 r.w Poznaniu, red. B. Szydłow ska-Cegłowa, J. Kozłowski, Poznań 1991, s. 45.

24 H. Janowska, Polska emigracja zarobkowa..., s. 244. Inne dane podaja, że w 1933 r. liczba Polaków naturalizowanych wynosiła ok. 30 tys. S. Jaros, op. cit., s. 68.

25 W lutym liczba Polaków przyjmujących obywatelstwo francuskie wyniosła 327 osób, a w marcu - 250 osób. AMAE, Série C, Administrative 1908-1940, sygn. 265, Naturalisations mars 1939, k. 117-119.

26 J. Gruszyński, op. cit., s. 106.

27 J. Ponty, Polonais méconnus..., s. 304-309; H. Ja now ska, Polska emigracja zarobkowa ..., s. 220-222; T. Olszański, Życie tułacze, Warszawa 1957, s. 343-352. 
Polaków, a według polskiego rządu liczba ta wynosiła 140355 osób. W porównaniu do 1931 r., w którym liczbę emigracji polskiej szacuje się jako największą, tzn. ponad 500 tys., według spisu ludności z marca 1936 r. polska społeczność we Francji liczyła prawie 100 tys. mniej - 422694 osoby $^{28}$.

Rząd polski próbował interweniować w sprawie niesprawiedliwego traktowania polskich robotników, ale wysiłki ze strony polskiej miały ograniczony charakter. W maju 1935 r. w czasie wizyty w Polsce Pierre'a Lavala, ministra spraw zagranicznych Francji, Jan Szembek, wiceminister spraw zagranicznych w polskim rządzie, zapytał gościa o sytuację polskich obywateli we Francji. Laval odpowiedział, że Francja ma pół miliona bezrobotnych i obywatele francuscy domagają się wydalenia cudzoziemców. Dodał jeszcze, że w rozmowie z Alfredem Chłapowskim, ambasadorem Polski, zapewnił, iż rząd francuski udzieli wszelkiej pomocy przy powrocie robotników do Polski. Władze polskie nie poruszały już kwestii „dobrowolnej reemigracji” robotników polskich w relacjach polsko-francuskich ${ }^{29}$.

Konwencja o emigracji nie wskazywała jednoznacznie, na koszt którego z państw polski obywatel ma zostać ekspulsowany. Zapewnienie transportu bezrobotnym cudzoziemcom regulowało rozporządzenie Pierre’a Lavala, ówczesnego ministra pracy i opieki społecznej, wydane 4 marca 1932 r. Wskazywało ono, że władze departamentalne są zobligowane do zapewnienia bezpłatnego transportu cudzoziemcom $\mathrm{i}$ ich rodzinom, które otrzymały nakaz ekspulsji ${ }^{30}$. Jednak w praktyce wyglądało to zupełnie inaczej. Niechęć do pokrywania kosztów podróży przez stronę francuską potwierdza również korespondencja Konsula Honorowego RP w Nicei do Ambasady RP w Paryżu. Do konsulatu zgłaszało się wielu bezrobotnych Polaków, którzy chcieli wrócić do kraju lub starali się o pozwolenie na dalszy pobyt na terytorium Francji, lecz to ostatnie, jak stwierdzano, „było prawie niemożliwe”. Zaznaczono, że wielokrotnie interweniowano w prefekturze w sprawie „bezpłatnych przejazdów” do Polski. Prefektura przychylała się do wniosków osób bezrobotnych „na ogół przychylnie” i wnioskowała do Ministerstwa Spraw Wewnętrznych Francji o wydanie bonu transportowego. Jednakże oczekiwanie na pozytywną decyzję przedłużało się do kilku miesięcy. Polacy, którzy otrzymali nakaz ekspulsji i tym samym utracili prawo do szukania zatrudnienia, pozostawali na utrzymaniu Komitetu Pomocy Bezrobotnym w Nicei w okresie oczekiwania na transport do Polski. Pomoc konsulatu w tym czasie nie oznaczała wcale zapewnienia spokoju osobie,

28 Liczba polskich Żydów zamieszkujących we Francji w 1939 r. wahała się między 80 a 90 tys. osób. J. Ponty, Polonais méconnus..., s. 310, 316, 319; H. Ja now sk a, Polska emigracja rarobkowa..., s. 106-107.

29 Ibidem, s. 176-177.

30 Archives Départementales du Pas-de-Calais [dalej cyt.: AD PdC], sygn. M 3175, Rapatriement de chômeurs, Pierre Laval Le Ministre du Travail et de la Prévoyance Sociale à Messieurs les Préfets, Paris, le 4 mars 1932, b.p. 
która otrzymała administracyjny nakaz ekspulsji. Niejednokrotnie, jak podaje konsul, Polacy, będąc na utrzymaniu Komitetu Pomocy Bezrobotnym, byli nękani przez francuska policję i aresztowani. Konsul podkreślił, że „trzeba wziąć pod uwagę opłakaną sytuację takiego wydalonego; bez mieszkania, stale głodny, szczuty przez policję. \Jednym] słowem, upadek zupełny"31.

Wydawać by się mogło, że przezwyciężenie kryzysu zakończy niepewny los polskiego górnika i robotnika we Francji. Sytuacja związana z wojną domową w Hiszpanii przyczyniła się jednak do utrzymania przez Francję ostrego kursu wobec cudzoziemców. $\mathrm{Na}$ mocy dekretu z 2 maja 1938 r. powołano do życia policję do spraw cudzoziemców ${ }^{32}$. Z pewnością dokument ten zezwalał na dokładniejsze kontrolowanie granicy hiszpańskiej i napływu uchodźców hiszpańskich po wybuchu wojny domowej w Hiszpanii. Teoretycznie dekret ten nie miał na celu kontroli obcokrajowców zamieszkujących od dawna we Francji, ale praktycznie zapisy m.in. artykułów 2. i 3. celowały w mieszkających tam od dawna obywateli cudzoziemskich. Zapis w artykule 2. dekretu o policji do spraw cudzoziemców nakazywał zgłoszenie do komisariatu policji lub merostwa każdej zmiany miejsca zamieszkania, nawet w tej samej miejscowości, i ubieganie się o wydanie nowego dowodu tożsamości. Zaniedbanie tego ze strony cudzoziemca miało być karane grzywną w wysokości od 2 do 12 tys. fr., a artykuł 3. tego dekretu zezwalał na wymierzenie cudzoziemcowi kary miesiąca pozbawienia wolności, jeżeli ten nie wystapił z prośbą o wydanie nowej karty pobytu w nakazanym terminie. Zapis o wymierzeniu kary był odnotowywany w kartotekach sądowych i tym samym utrudniał znalezienie zatrudnienia. Artykuł 7. nakazywał zgłoszenie do merostwa każdorazowo wyjazdu i przyjazdu do Francji przez obcokrajowców.

Natomiast Polacy, którzy byli członkami Brygad Międzynarodowych i przybyli z Hiszpanii, nie mogli się ubiegać o kartę pobytu dla obcokrajowców. Dla władz francuskich stawali się „bezpaństwowcami”33. Traktowanie dąbrowszczaków jako „bezpaństwowców" znajdowało podstawę w ustawie władz polskich z 11 marca 1938 r., która zezwalała na odebranie obywatelstwa polskiego emigrantom działającym ,na szkodę państwa polskiego"34.

31 Archiwum Akt Nowych [dalej cyt.: AAN], Konsulat Honorowy RP w Nicei, sygn. 244, Pismo do Ambasady RP w Paryżu, 6 VI 1936 r., k. 142-143.

32 J. Ponty, L'immigration dans les textes..., s. 224-226, 229.

33 J. Ponty, Polonais méconnus..., s. 342; ea dem, L'immigration dans les textes..., s. 229-232; Archives Départementales des Pyrénées-Orientales [dalej cyt.: AD PO], sygn. 109 W 297, Raport du Ministre de l'Intérieur Albert Sarraut au Président de la République Française, Paris, 2 V 1938, b.p.

34 Ustawa ta obowiązywała w momencie tworzenia rządu gen. Władysława Sikorskiego w 1939 r., który nie przyjmował w szeregi polskiej armii członków Brygad Międzynarodowych. K. Maj, Polscy komuniści we Francji, 1919-1946, Warszawa 1971, s. 32-33. 
Albert Sarraut w piśmie z 28 maja 1938 r. skierowanym do prefektów zaznaczył, że uchodźcy polityczni lub „bezpaństwowcy” powinni być uważani za „niepożądanych” w kraju i należy ich „objąć” szczególnym zainteresowaniem oraz umieścić w ośrodkach odosobnienia. Nakazywał on organizowanie środków transportu do granicy państwa francuskiego w celu wydalenia „niepożądanych” cudzoziemców, a ci uznani za niebezpiecznych mieli być wywiezieni do granicy pod eskorta ${ }^{35}$. Następne obostrzenia celowały w stowarzyszenia i organizacje emigranckie: dekretem z 12 kwietnia 1939 r. ograniczone zostały prawa cudzoziemców do organizowania i zakładania stowarzyszeń, konfiskowano emigracyjne czasopisma komunistyczne, np. „Dziennik Ludowy” wydawany przez członków grup polskich przy Francuskiej Partii Komunistycznej (FPK). Organizacje i stowarzyszenia emigracyjne mogły zostać zalegalizowane po uprzednim otrzymaniu zgody ministra spraw wewnętrznych Francji, autoryzację wydawano im na czas określony, a odnowienie jej wymagało ponownych starań w resorcie spraw wewnętrznych o zalegalizowanie organizacji ${ }^{36}$.

Kolejny opublikowany dekret z mocą ustawy z 12 listopada 1938 r. zezwalał na internowanie imigrantów w obozach i specjalnych ośrodkach. Pierwszy taki obóz, utworzony na mocy kolejnego dekretu z mocą ustawy z 21 stycznia 1939 r., mieścił się w Rieucros w departamencie Lozère ${ }^{37}$. Następne obozy przeznaczone dla uchodźców hiszpańskich założone zostały wiosną 1939 r., m.in. w Gurs w departamencie Basses-Pyrénées (obecnie Pyrénées-Atlantiques), Saint-Cyprien, Argelès-sur-Mer w departamencie Pyrénées-Orientales.

\section{Wojna i jej wpływ na sytuację Polaków we Francji}

Po wypowiedzeniu przez Francję wojny z Niemcami władze francuskie wymogły opublikowanym 18 listopada 1939 r. dekretem z mocą ustawy (nazwanym „dekretem Daladiera") internowanie w obozach odosobnienia lub wydalenie z Francji na podstawie decyzji prefekta osób niebezpiecznych dla państwa francuskiego oraz bezpieczeństwa

35 AD PO, sygn. 109 W 297, Le Ministre de l'Intérieur à Monsieur le Gouverneur Général de l'Algérie, à Monsieur le Préfet de Police, à Messieurs les Préfets, Paris, 28 V 1938 et 21 XI 1938, b.p.; M. Gmurczyk-Wrońska, Polska - niepotrzebny aliant Francii? (Francja wobec Polski w latach 1938-1944), Warszawa 2003, s. 192.

36 H. Janow ska, Polska emigracja zarobkowa..., s. 180.

37 Indésirables en France 1938-1942. Dossier pédagogique no 7, s. 8-9. Ponadto na mocy dekretu z 12 XI 1938 r. obcokrajowiec mógł wziąc ślub we Francji, jeśli przedstawił dokument potwierdzający jego pobyt w kraju od ponad roku. Ci cudzoziemcy, którzy utrzymywali się z handlu i chcieli założyć swoja działalność po 12 XI 1938 r., musieli przedstawić kartę pobytu ważną od trzech lat. W żadnym wypadku nie były brane pod uwagę karty czasowego pobytu. J. Ponty, Polonais méconnus..., s. 343; eadem, L'immigration dans les textes..., s. 227; P. Weil, op. cit., s. 28. 
publicznego. Po jego opublikowaniu do obozów przywożono emigrantów oraz osoby oskarżone o przestępstwa polityczne ${ }^{38}$. Internowano ich w obozach istniejących od wiosny 1939 r., jak obóz Gurs, oraz tych zakładanych od września 1939 r., jak m.in. Le Vernet w departamencie Ariège, Les Milles w departamencie Bouches du Rhône. Za niebezpiecznych dla państwa francuskiego uznawano m.in. komunistów, którym dekretem z mocą ustawy z 26 września 1939 r. zdelegalizowano struktury FPK oraz ok. 700 organizacji o charakterze lewicowym, zaś ich mienie i lokale skonfiskowano. Zawieszono komunistycznych radnych i przedstawicieli samorządów. Aresztowano działaczy, również wśród polskiej emigracji.

Po ataku Niemiec na Francję władze francuskie wymogły okólnikiem z 15 maja 1940 r. internowanie wszystkich uchodźców wrogich nacji. Najpierw mężczyzn od 17. do 65. roku życia, a dwa dni później, tj. 17 maja, tym okólnikiem zostały objęte również kobiety. Mężczyźni byli kierowani do obozu w Rivesaltes, a kobiety do obozu w Gurs. Po kapitulacji Francji w czerwcu 1940 r. w obozie Gurs osadzono 9283 osoby (głównie kobiety i dzieci) ${ }^{39}$. Byli to Niemcy, Austriacy, Czesi, Polacy, Jugosłowianie, Bułgarzy oraz Hiszpanie. W maju i czerwcu 1940 r. zamknięto w obozie 9771 emigrantów, czyli internowano obywateli innych narodowości nieposiadających uregulowanych spraw związanych z pobytem na terytorium Francji Spośród nich największą liczbę stanowili Niemcy i Austriacy ${ }^{40}$.

Na mocy porozumienia w Rethondes, podpisanego 22 czerwca 1940 r., Francję podzielono linią demarkacyjną na część okupowaną i nieokupowaną ${ }^{41}$. Obozy interno-

38 J.O. z 19 XI 1939 r., s. 13218, [cyt za:] Indésirables en France 1938-1942. Dossierpédagogique...; C. La harie, Le camp de Gurs, 1939-1945. Un aspect méconnu de l'bistoire de Vichy, Pau 1993, s. 57.

39 Okólnik nie obejmował Francuzek, które po poślubieniu obcokrajowca stracily obywatelstwo francuskie, Austriaczek, Niemek, które miały dzieci posiadające obywatelstwo francuskie, kobiet ciężarnych oraz kobiet posiadających dzieci do 16. roku życia. D. Peschan ski, La France des camps. L'internement, 19381946, Paris 2002, s. 152. W październiku 1940 r. władze francuskie zadecydowały, że obcokrajowcy, których uznano za niebezpiecznych dla porządku publicznego, mieli być internowani w dwóch obozach: mężczyźni w obozie Le Vernet, kobiety w obozie Rieucros. Ponadto cudzoziemcy, którzy nielegalnie przekroczyli linię demarkacyjną, mieli być kierowani do obozu Agde i Montélimar. Archives Départementales d'Ariège [dalej: AD A], sygn. 5 W 142, Officiel Officiel, Intérieur Sûreté 7ème Bureau à Préfets de la Zone libre, Circulaire, b.p.

40 C. Laharie, op. cit., s. 143.

41 Na mocy zawieszenia broni strefa północna wraz z wybrzeżem atlantyckim i Paryżem, obejmująca około dwie trzecie powierzchni Francji, została zajęta przez Niemców (Zone Nord - ZN, Zone Occupée - ZO). Południowa strefa, tzw. wolna (Zone Sud - ZS, Zone Libre - ZL), ze stolicą w Vichy, była administrowana przez francuski rząd, który zachowywał flotę wojenną wraz z jej bazami nad Morzem Śródziemnym, kolonialne imperium i stutysięczną armię. Koszty pobytu okupacyjnych wojsk niemieckich miała pokrywać strona francuska. W ostatnim artykule konwencji o zawieszeniu broni Niemcy zastrzegli sobie prawo do wypowiedzenia układu w każdej chwili, jeżeli rząd francuski nie wypełni zaciagniętych zobowiązań. Alzacja i Lotaryngia zostały bezpośrednio włączone do Rzeszy. Weeglowe zagłębie północne (region Nord-Pas-de-Calais), jako część strefy zakazanej (Zone 
wania na południu Francji podlegały rządowi Vichy i prefekturom, na terenie których się znajdowały.

Miasteczko Gurs, gdzie założono wspomniany wcześniej obóz, położone jest w dolinie Oloron między Oloron-Sainte-Marie i Navarrenx niedaleko granicy z Hiszpanią. Duże znaczenie w wyborze lokalizacji obozu miała znajdująca się $17 \mathrm{~km}$ od Gurs stacja kolejowa, która w przyszłości odegrała ważną rolę w jego funkcjonowaniu. Obóz rozmieszczony został na terenie wiosek Préchacq-Josbaig, Dognen i Gurs i obejmował ok. 80 ha. Ministerstwo Spraw Wewnętrznych Francji 15 marca 1939 r. podjęło decyzję o założeniu ośrodka odosobnienia (centre d'accuei). Prace zakończono 25 kwietnia 1939 r. Już w kwietniu 1939 r. umieszczono tam blisko 15 tys. osób. Obóz ogrodzono łańcuchem o długości $250 \mathrm{~km}$. Oświetlenie było przewidziane na terenie całego obozu, z wyjątkiem baraków dla uchodźców ${ }^{42}$.

Według Euzebiusza Dworkina, jednego z ochotników Brygad Międzynarodowych, obóz ,był podzielony na «wysepki» (îlots), po dwanaście baraków w każdej, dwa szeregi po sześć baraków. Każda «wysepka» miała poza tym swą kuchnię, izbę chorych, ustępy. «Wysepki» oddzielone były od siebie podwójnym rzędem drutów kolczastych”. Obfite deszcze charakterystyczne dla oceanicznego klimatu były przyczyną częstego zalewania obozu, wskutek czego internowani ,grzęźli po kostki [...] w gęstej lepkiej glinie"43. Natomiast założony także na podgórzu pirenejskim obóz Le Vernet, w pobliżu którego znajdowała się stacja kolejowa, był podzielony na 3 oddziały: A, B, C. W oddziale A internowano skazanych za przestępstwa kryminalne, w oddziale B umieszczono komunistów i anarchistów, w oddziale C znaleźli się obywatele określeni mianem „podejrzanych” (w tej grupie znajdowali się m.in. ochotnicy Legii Cudzoziemskiej, Żydzi, rolnicy, a także ci, którzy nie posiadali dostatecznych środków na utrzymanie). W 1940 r. liczba Polaków w obozie Le Vernet wynosiła 700 osób. Oddziały były od siebie izolowane drutem kolczastym i strażą wojskowa.

Pierwsze transporty do obozu Gurs przybyły w dniach od 5 kwietnia do 10 maja 1939 r. Przywieziono w tym okresie 18985 mężczyzn. Znajdowali się tam m.in. Baskowie, Hiszpanie, a także 6,8 tys. członków Brygad Międzynarodowych. Ci ostatni zostali przywiezieni z obozu Argelès-sur-Mer i Saint-Cyprien ${ }^{44}$. Pierwsi Polacy trafili do obozu Gurs już wiosną 1939 r. i byli to uczestnicy wojny domowej w Hiszpanii.

Interdite - ZI), włączono do belgijskiego obszaru okupacyjnego. J. Eisler, Kolaboracja we Francii, 19401944, Warszawa 1989, s. 72-73; J. P. Azéma, O. Wieviorka, Vichy 1940-1944, Paris 2004, s. 35-37; O kapitulacji Francji i tworzeniu rządu Vichy zob. m.in.: R. Aron, Histoire de Vichy, Paris 1954.

42 Obóz w Gurs budowano w pośpiechu, aby rozluźnić istniejące już wtedy przeludnienie w obozie w Roussillon. C. Laharie, op. cit., s. 26-34; D. Peschan ski, op. cit., s. 43-44, 101.

43 E. Dworkin, Od Manzanares do Oki. Wspomnienia dabrowszczaka, Warszawa 1974, s. 17-18.

44 D. Peschanski, op. cit., s. 44; C. Laharie, op. cit., s. 76. 
Claude Laharie podaje, że w maju 1939 r. było 904 Polaków, a miesiąc później - 950, którzy zajmowali swoja „wysepkę"45. Mieszkające na południu Francji Polki sympatyzujące z FPK opiekowały się dąbrowszczakami uwięzionymi w obozach na południu Francji - Argelès-sur-Mer, Gurs i Le Vernet - oraz rodzinami aresztowanych polskich komunistów, za co były szykanowane przez władze francuskie.

Obóz Gurs, jak już wspomniano, pierwotnie miał być przeznaczony dla uchodźców hiszpańskich. W czasie budowy jego pełna nazwa brzmiała: Ośrodek odosobnienia uchodźców hiszpańskich w Gurs (Centre d'accueil des réfugiés espagnoles de Gurs). Pilnowany był przez strażników. Szef obozu oraz strażnicy podlegali władzom prefekturalnym w Pau oraz dowódcy wojsk 18. Regionu w Bordeaux ${ }^{46}$. W początkowym okresie funkcjonowania obozy nie były jednak surowo dozorowane. Można powiedzieć, że cieszyły się względną swoboda. Pomimo fatalnych warunków sanitarnych osadzeni mieli kontakt z okoliczną ludnością, która donosiła im żywność i ubrania, dopuszczalne były wizyty towarzyskie. Ci, którzy odwiedzali internowanych, niejednokrotnie przyczyniali się do ułatwienia im ucieczki. Sytuacja ta zmieniła się jesienią $1940 \mathrm{r}$.

Od października 1940 r. władze Vichy zmieniły status obozu Gurs, który stał się obozem „półkarnym”. Zmiana ta została opublikowana w okólniku ministra spraw wewnętrznych z 20 października 1940 r. Odtąd cudzoziemców traktowano jako ,niepożądanych” i „niebezpiecznych dla państwa francuskiego”. Mieli oni zostać umieszczeni w obozie „,pod ścisłym nadzorem”. Zapis okólnika dotyczył m.in. uchodźców niemieckich, austriackich oraz członków Brygad Międzynarodowych, których władze Sztabu Generalnego nie wcieliły jeszcze do Grup Robotników Cudzoziemskich (Groupements de travailleurs étrangers - GTE). Strażników pilnujących ośrodka zastąpiono gwardią i żandarmerią, a Gurs stał się obozem o surowej dyscyplinie. Obok Gurs w wykazie zostały wymienione również inne obozy w strefie nieokupowanej z przeznaczeniem dla cudzoziemców. Były to obozy: Le Vernet, Argelès-sur-Mer, Bram, Saint-Cyprien i Les Milles, do których kierowano w pierwszej kolejności Żydów przebywających we Francji i posiadających inne obywatelstwo niż francuskie. Internowanie Żydów zostało usankcjonowane dekretem z mocą ustawy z 4 października 1940 r. ${ }^{47}$, który zezwalał na umieszczenie ich w obozach internowania na podstawie decyzji prefekta ${ }^{48}$.

45 Ibidem, s. 104; E. Dworkin, op. cit., s. 18.

46 C. Laharie, op. cit., s. 56.

47 J.O. z 18 X 1940 r., s. 5324, [cyt. za:] Indésirables en France 1938-1942. Dossier pédagogique....

48 C. Laharie, op. cit., s. 58; D. Peschanski, op. cit., s. 208; Archives Départementales des PyrénéesAtlantiques [dalej cyt.: AD PA], sygn. 54 W 14, [copie] Note de service du Général d'Armée Sciard Commandant la 17e Division Militaire, Toulouse, le 26 XI 1940, b.p. Pół roku później ustawa z 2 VI 1941 r. nakazywała wykonanie władzom administracyjnym spisu Żydów zamieszkujących we Francji. W 2. artykule ustawa przewidywała karę w przypadku złamania prawa ,bez ujmy praw dla prefekta orzekającego o internowaniu, nawet jeśli zainteresowany jest Francuzem”. Okólnik z 25 VI 1941 r. 
Ostatecznie obozy Gurs, Le Vernet i Argelès-sur-Mer zostały przeznaczone dla obcokrajowców i jednocześnie określony został precyzyjnie ich charakter. Do obozu Le Vernet mieli być kierowani cudzoziemcy podejrzani o czyny przestępcze i polityczne ${ }^{49}$, obóz w Gurs uzyskał status obozu „półkarnego” i przeznaczony został dla osób podlegających szczególnej obserwacji, a w obozie Argelès-sur-Mer umieszczona została reszta „niepożądanych” cudzoziemców, która nie wzbudzała znacznego zainteresowania władz francuskich (element calme). Do obozu w Gurs od października 1940 r. do listopada 1943 r. przywieziono 18185 osób. Do 1941 r. liczba Polaków w obozach wynosiła do kilkuset osób ${ }^{50}$.

Z początkiem 1941 r. władze Vichy po raz kolejny zmieniły charakter obozów Gurs, Argelès-sur-Mer oraz Le Vernet i Rieucros. Obóz Gurs przestał być obozem „półkarnym” i stał się „ośrodkiem zakwaterowania” (centre d'bébergement) dla cudzoziemców. Od tego momentu obóz został przeznaczony przede wszystkim dla obcokrajowców pochodzenia żydowskiego (głównie kobiet i dzieci). Wiceminister spraw wewnętrznych w rządzie Vichy, Marcel Peyrouton, w korespondencji do prefektów w wolnej strefie określił, że obozy Le Vernet i Rieucros otrzymują status obozów koncentracyjnych, a cudzoziemcy tam się znajdujący mieli być nazywani internowanymi. Obozy Gurs i Argelès-sur-Mer stały się „ośrodkami zakwaterowania” dla cudzoziemców, a umieszczone tam osoby nazywane były „zakwaterowanymi”, którym zapewniano „schronienie" 51 . Władze Vichy w sprawozdaniu stwierdzały, że obozy o specjalnym nadzorze dla cudzoziemców „sa jak prawdziwe więzienia o surowej dyscyplinie, otoczone drutami kolczastymi, pilnowane przez uzbrojonych strażników”. Do takich obozów zaliczono obóz dla mężczyzn Le Vernet i podobny dla kobiet - Brens.

W dniu 1 stycznia 1941 r. w obozie Gurs znajdowało się 11825 mężczyzn. Prawie 90 proc. internowanych stanowili Żydzi, z których najliczniejszą grupa byli obywatele

wzmocnił jeszcze ustawę z 4 X 1940 r. Na mocy tego okólnika nie wolno było uwolnić żadnej osoby pochodzenia żydowskiego obcej narodowości, która nie mieszkała na stałe we Francji przed 10 V 1940 r. D. Peschanski, op. cit., s. 169-170.

49 Obóz podlegał nadzorowi Ministerstwa Spraw Wewnętrznych Francji, a uzyskanie zwolnienia z niego było bardzo trudne. Nie wszyscy tam internowani byli „niebezpieczni dla państwa francuskiego”. Bardzo często umieszczano tam osoby, co do których administracja francuska nie wiedziała, jakie zająć stanowisko, i ,z nadmiaru ostrożności skierowano ich do Vernet d'Ariège”. AAN, Konsulat RP w Tuluzie, sygn. 1, Sprawozdanie z wizytacji obozu internowanych w Vernet d'Ariège (Ariège), k. 1.

$50 \quad$ C. Laharie, op. cit., s. 166, 181.

51 Ibidem, s. 59; AD PO, sygn. 109 W 297, Le Ministre Secrétaire d'État à l'Intérieur à Messieurs les Préfets de la Zone Libre, à Messieurs les Sous-Préfets de: Montmorillon, Montluçon, Saint-Amand, Vichy, 19 I 1941, b.p.; AMAE, Contrôle des étrangers, Service des étrangers 1916-1944, sygn. 6, Rapports, Note sur les camps d'internement et d'hébergement de la zone sude, k. 1. 
niemieccy, zaś polscy obywatele stanowili 5,1 proc. internowanych Żydów ${ }^{52}$. Według innego sprawozdania w 1941 r. w obozie Gurs internowano 4573 osoby. Liczba Polaków wynosiła 357 osób $^{53}$. Podobne dane statystyczne za rok 1941 odnaleziono w Archiwum Departamentalnym w Pau. W połowie 1941 r. w obozie Gurs było internowanych 301 Polaków: 161 kobiet, 134 mężczyzn oraz 6 dzieciri ${ }^{54}$ W 1942 r. liczebność polskich obywateli w obozach na południu Francji przedstawiała się następująco: w obozie Le Vernet przebywało 92 Polaków, w Brens - 31, w Gurs - 357, w Noé - 70 osób ${ }^{55}$. Dwa lata później, w październiku 1944 r. w obozie Gurs przebywało 11 Polaków: 1 mężczyzna i 10 kobiet $^{56}$.

Osoby internowane były też przewożone do innych obozów. Pierwsze konwoje z obozu Gurs zostały zorganizowane w październiku 1940 r. po zmianie statusu obozu Gurs. Hiszpanie zostali przewiezieni do obozu Rivesaltes. Utworzenie dwóch nowych obozów w departamencie Haute-Garonne o statucie camps-hôpitaux $x^{57}$ przyczyniło się do zorganizowania przewozu osób starszych i dzieci do obozów Noé i Récébédou ${ }^{58}$. Transporty do tych dwóch obozów trwały od końca 1940 do 1943 r. W listopadzie 1940 r. do obozu Noé przywieziono 58 Polaków, zaś ogólna liczba internowanych cudzoziemców

52 C. Laharie, op. cit., s. 182. Do maja 1941 r. w obozie Gurs internowano około 20 tys. osób. AD PA, sygn. 72 W 30, Le Médecin Inspecteur départemental de la Santé à Monsieur le Directeur Régional à la Famille et à la Santé, $6 \mathrm{~V}$ 1941, b.p.

53 AMAE, Contrôle des étrangers, Service des étrangers 1916-1944, sygn. 6, Rapports, Note sur les camps d'internement et d'hébergement de la zone sude; Camp de Gurs, k. 1. Stan liczebny w obozach na południu Francji w lutym 1942 r. wynosił 15 tys. obcokrajowców, z czego około 7 tys. Żydów i 4 tys. obywateli hiszpańskich. Ibidem, k. 2.

54 AD PA, sygn. 72 W 42, Le Commissaire Spécial Chef du Centre Gurs à Monsieur le Préfet des BassesPyrenées, 17 VII 1941, b.p.

55 AMAE, Contrôle des étrangers, Service des étrangers 1916-1944, sygn. 6, Rapports, Note sur les camps d'internement et d'hébergement de la zone sude, Liste des camps et des centres d'accueil de la zone sude dans lesquels sont internés ou hébergés des ressortissants de nos differants bureaux d'administration avec statistiques des dits ressortissants, k. 6.

56 AD PA, sygn. 77 W 14, Le Commissaire Principal Chef du Camp de Gurs à Monsieur le Directeur Dépatemental de la Police à Pau, 19 X 1944, b.p.

57 „Obozy-szpitale” utworzono w lutym 1941 r. Były one przeznaczone dla osób starszych powyżej 65. roku życia i kobiet z dziećmi. É. Malo, Le camp de Noé, 1941-1947, Pau 2009, s. 13-15.

58 Od 21 do 27 II 1941 r. 601 osób starszych zostało przewiezionych do obozu Noé w departamencie Haute-Garonne, a w marcu 1941 r. 875 osób chorych i starszych przewieziono do obozu Récébédou w tym samym departamencie. W tym samym czasie dzieci i ich rodziny zostały przewiezione do obozu Rivesaltes w departamencie Pyrénées Orientales. W 1941 r. 1226 osób przetransportowano z obozu w Gurs do innych obozów na terenie Francji. C. Laharie, op. cit., s. 220; D. Peschanski, op. cit., s. 236. W instrukcji z 22 lutego 1941 r. do przygotowania transportu na 27 lutego 1941 r. z obozu Gurs do obozu Noé zaznaczono, że liczba przewożonych osób nie mogła wynieść więcej niż 310. W tej liczbie znajdować się miały również pielęgniarki i służba medyczna. Zapewniano również wyżywienie na dwa pierwsze dni pobytu w obozie Noé. AD PA, sygn. 72 W 44, Le Préfet des Basses-Pyrénées à Monsieur le Commissaire Spécial Chef du Camp de Gurs, Pau, le 22 février 1941, b.p. 
wynosiła 1240 osoby. W 1943 r. liczba internowanych wzrosła do 1700 osób, z czego liczba Polaków wynosiła 70 osób ${ }^{50}$.

Deportacje internowanych odbywały się również poprzez włączenie mężczyzn zdolnych do pracy do GTE, powołanych dekretem pod koniec 1940 r. przez władze Vichy, które instrukcjami nakazały włączenie cudzoziemskich mężczyzn od 18. do 55. roku życia do GTE. W ich szeregach, jak podaje Jan E. Zamojski, znalazła się duża liczba Polaków ${ }^{60}$. W większości przypadków włączenie do GTE oznaczało wywiezienie na roboty przymusowe do Niemiec i pracę na rzecz Organizacji Todt. Od października 1940 r. do 1943 r. z obozu Gurs wcielono do GTE 2280 mężczyzn. Powołanie GTE we wrześniu $1940 \mathrm{r}$. rozwiązywało zarówno problem polityczny, jak i socjalny w kwestii cudzoziemców, którzy zaciagnięci do GTE, byli wykorzystywani do prac na południu Francji. Od listopada 1940 r. 40 tys. osób pracowało na rzecz organizacji Todt przy budowie Wału Atlantyckiego, a od 1942 r. z obozów internowania deportowano przetrzymywanych w nich cudzoziemców do prac przymusowych dla Organizacji Todt ${ }^{61}$.

Od 1942 r. administracja francuska rozpoczęła wywózki ludności żydowskiej do niemieckich obozów zagłady. Tylko od 6 sierpnia 1942 r. do 3 marca 1943 r. obóz Gurs opuściło w 6 transportach „w nieznanym kierunku” (pour une destination inconnue) 3907 osób $^{62}$. Ten „nieznany kierunek” oznaczał transport do obozu Drancy, a następnie do obozu zagłady w Sobiborze lub do obozu koncentracyjnego (później zagłady) Auschwitz-Birkenau. Wśród deportowanych aż 95,2 proc. stanowili Żydzi, z czego 29,5 proc. byli to Żydzi polscy ${ }^{63}$. W Le Vernet wagony, którymi wywożono Żydów, więźniowie nazywali les wagon-fantômes (wagony-duchy) ${ }^{64}$.

59 AMAE, Contrôle des étrangers, Service des étrangers 1916-1944, sygn. 6, Rapports, Note sur les camps d'internement et d'hébergement de la zone sude; Camp de Noé, k. 1-2.

60 J.E. Zamojski, Polacy w ruchu oporu we Francji, 1940-1945, Wrocław-Warszawa-Kraków-Gdańsk 1975, s. $80-84$.

61 D. Peschanski, op. cit., s. 138, 224-225, 341; C. Laharie, op. cit., s. 223-224.

62 Listy z 25 VIII 1942 r., 1 IX 1942 r. i 2 III 1943 r. osób deportowanych w transportach w „nieznanym kierunku”, czyt. AD PA, sygn. 77 W 23, Transferts des internés; instructions (1942-1945), arrivées à Gurs (1940-1943), rapatriement et autorisation de transit (1941), listes nominatives des internés partis pour d'autres camps ou pour une destintion inconnue (1940-1944). Internés partis pour destination inconnue (1942-1943); C. Laharie, op. cit., s. 236.

${ }^{63}$ Ibidem, s. 236-245. Z terenów całej Francji deportowano 76 tys. Żydów w 77 konwojach. 69 tys. zostało wysłanych do Auschwitz-Birkenau, z czego 42 tys. zostało skierowanych do komór gazowych od razu po przybyciu do obozu. Wojnę przeżyło zaledwie 2,5 tys. Żydów. Deportacje w największym procencie dotknęły Żydów innych narodowości. Na 76 tys. deportowanych prawie 50 tys. to byli Żydzi obcej narodowości, 8 tys. - Żydzi naturalizowani i 8 tys. - Żydzi, których rodzice byli Francuzami. D. Peschanski, op. cit., 348 .

64 Według Peschanskiego za deportację Żydów z terytorium Francji odpowiedzialne były okupacyjne władze niemieckie. Uważa on, że naziści, chcąc zapewnić sobie możliwość skutecznej akcji deportacyjnej, postanowili jej organizacją obciążyć lokalne władze. Autor stoi na stanowisku, że pertraktacje 
Zwolnienie z obozu obwarowane było kilkoma warunkami. Oprócz deklaracji opuszczenia Francji internowany musiał przedstawić zezwolenie na pobyt na terytorium francuskim wydane przez jednego z prefektów strefy nieokupowanej oraz dokument poświadczający, że jest on w posiadaniu wystarczających środków materialnych gwarantujących samodzielne utrzymanie. Zwolnienie z obozu zapewniały także zaświadczenia, m.in. o zatrudnieniu w rolnictwie (o takie zaświadczenia starała się m.in. Rosa Bailly, fundatorka Les Amis de la Pologne). Ostateczna decyzja w tej sprawie zależała jednak od stanowiska Ministerstwa Spraw Wewnętrznych Francji. Najbardziej zdeterminowani nie ustawali w staraniach o wizy wyjazdowe, głównie do Stanów Zjednoczonych. Jednak skomplikowane formalności i długi czas oczekiwania na odpowiedź nie wróżyły pozytywnego załatwienia sprawy ${ }^{65}$.

Tylko w obozie Gurs spośród 1940 mężczyzn i kobiet 580 osobom nie udało się załatwić tych formalności ${ }^{66}$. Ci, którzy otrzymali wizę na wyjazd, oczekiwali na opuszczenie Francji na terenie Marsylii w obozie Les Milles lub w hotelach Terminus i Bompard. Ten ostatni był przeznaczony dla kobiet. Jak podaje C. Laharie, od stycznia do czerwca 1941 r. do obozu Les Milles zostały przewiezione 1764 osoby $^{67}$.

W obozach władze vichystowskie zapewniały elementarne warunki higieny i opieki medycznej oraz podstawowe wyżywienie. Według sprawozdań w „rządowych” obozach znajdowała się służba medyczna; były też systematycznie wizytowane przez lekarzy. Jednak „opieka” władz francuskich pozostawiała wiele do życzenia ${ }^{68}$.

oraz kompromisy były koniecznością ze strony Philippe’a Pétaina, nawet za cenę utrzymania tzw. suwerenności i dlatego w negocjacje z rządem niemieckim została włączona kwestia deportacji ludności żydowskiej. D. Peschanski, op. cit., s. 347-348. Tezy Peschanskiego nie da się jednak obronić. Już Robert Paxton stwierdził, że nie można zwolnić władz Vichy z odpowiedzialności za udział w dyskryminacji ludności żydowskiej w czasie II wojny światowej. Specjalne obozy odosobnienia i dekrety stanowiące o internowaniu Żydów zamieszkujących terytorium Francji oraz dekret z 3 października 1940 r., wykluczający społeczność żydowską z życia społecznego, politycznego i kulturalnego Francji, były inicjatywą reżimu Vichy, zanim Hitler zaczął wywierać presję na Pétaina. R.O. Paxton, La France de Vichy, 1940-1944, Paris 1973, s. 171-172. W październiku 2010 r. francuskie media informowały o odnalezionym oryginale dokumentu z października 1940 r., który sankcjonował legalną dyskryminację Żydów we Francji. O odkryciu dokumentu powiadomił adwokat Serge Klarsfeld, nazywany łowca nazistów. Jego zdaniem za prześladowania ludności żydowskiej odpowiadał marszałek Pétain, który dokonał sam odręcznych poprawek w maszynopisie. Według tego dokumentu Pétain zaostrzył dyskryminację nie tylko wobec Żydów cudzoziemskich, ale również francuskich. Odnaleziony maszynopis obala istniejący we Francji pogląd, że Pétain chronił francuskich Żydówm i potwierdza, że rząd Vichy bez nacisków niemieckich przygotował projekt dyskryminacji ludności żydowskiej.

65 AMAE, Contrôle des étrangers, Service des étrangers 1916-1944, sygn. 6, Rapports, Note sur les camps d'internement et d'hébergement de la zone sude, k. 3; AAN, Konsulat RP w Tuluzie, sygn. 1, Sprawozdanie z wizytacji obozu internowanych w Vernet d'Ariège (Ariège), k. 5.

${ }_{66}$ C. Laharie, op. cit., s. 225.

67 Ibidem.

68 AMAE, Contrôle des étrangers, Service des étrangers 1916-1944, sygn. 6, Rapports, Note sur les camps d'internement et d'hébergement de la zone sude, k. 3. 
Wyżywienie było niewystarczające, stan odzieży niesatysfakcjonujący, baraki były w złym stanie, najczęściej zawilgocone. To wszystko powodowało, że internowani byli w słabej formie moralnej i fizycznej, nawet ci, którzy mieli być wykorzystywani jako siła robocza ${ }^{69}$. Mieli objawy gorączki tyfusowej i boreliozy ${ }^{70}$.

W Le Vernet, podobnie jak w Gurs, internowani mieszkali w barakach, na drewnianych pryczach rozłożona była słoma, gdzie „w następstwie tego stan zarobaczenia jest niesłychany, gdyż robactwo gnieździ się w drzewie i słomie zmienianej co trzy miesiące"71. Noce były bardzo zimne, natomiast w dzień upały były „nie do wytrzymania”. Internowani byli niedożywieni, racje żywnościowe systematycznie zmniejszano. Do tego jeszcze bezczynność, jaka panowała w obozie, również działała demoralizująco ${ }^{72}$.

Polskich obywateli opieką obejmowały polskie placówki i organizacje charytatywne, jak Biura Polskie, które powstawały w miejsce polskich placówek dyplomatycznych od 1 października 1940 r., oraz PCK, przemianowane w pierwszych miesiącach 1941 r. na TOPF. Do prac PCK włączył się Zarząd Związku Polaków we Francji. Po rozwiązaniu PCK przez Francuzów i zalegalizowaniu nowej organizacji TOPF przejęło personel, wszystkie schroniska oraz fundusze. Prezesem TOPF został Zygmunt Zaleski ${ }^{73}$, a po jego aresztowaniu - Józef Jakubowski ${ }^{74}$.

69 Jean Pochard był członkiem służby socjalnej zespołu obcokrajowców, którzy wizytowali obóz od 10 do 25 VI 1941 r. D. Peschanski, op. cit., s. 402, 521; C. Laharie dokładniej opisał warunki higieny i życia w obozie: C. Laharie, op. cit., s. 326-339. O warunkach w obozie można przeczytać również we wspomnieniach zebranych w książce: M. Cheniaux assistée par J. Miqueu, Le camp de Gurs (1939-1945). Un ensemble de témoignages dont celui d'Hanna Schramm, 2009 oraz w artykule: A. Grynberg, Les camps du sud de la France: de l'internement à la déportation, „Annales. Économies, Sociétés, Civilisations” 1993, no 3.

70 Śmiertelność w obozie była najwyższa wśród osób starszych, powyżej 50. roku życia. W raporcie z 11 XI 1940 r. do prefekta departamentu Basses-Pyrénées lekarz wizytujący obóz Gurs napisal, że na 63 zgony zanotowane od 28 X 1940 r. 43 osoby umarły ze starości, 13 z powodu chorób serca, 7 wskutek innych chorób przewlekłych. AD PA, sygn. 72 W 30, Le médecin inspecteur de la Santé à Monsieur le Prefet des Basses Pyrénées, 11 XI 1940, b.p.

71 AAN, Konsulat RP w Tuluzie, sygn. 1, Sprawozdanie z wizytacji obozu internowanych w Vernet d'Ariège (Ariège), k. 1.

72 Ibidem, k. 5.

73 Zygmunt Zaleski został formalnie mianowany prezesem TOPF listem z 13 czerwca 1941 r., a na sekretarza generalnego wybrano Józefa Jakubowskiego. Z. Lubicz-Zaleski, Pamietnik, t. 2: Od Grotowic do Buchenwaldu (1939-1945), oprac., wstęp i przypisami opatrzyła M. Willa u me, Paryż-Łódź 1998, s. 131 i następne. O działalności PCK we Francji czyt. M. Biesiekierski, Polska akcja opiekuńcza we Francji w okresie okupacji niemieckiej (czerwiec 1940 - wrzesien 1944), „Zeszyty Historyczne” (Paryż) 1993, z. 105, s. 38-63 oraz S. Zabiełło, Na posterunku we Francji, Warszawa 1967.

74 P. Kalinow ski, Emigracja polska we Francji w stużbie dla Polski i Francji, 1939-1945, Paryż 1970, s. 3033. W korespondencji do prefektów i podprefektów wiceminister spraw wewnętrznych wymienił wszystkich delegatów PCK mianowanych 21 I 1941 r. Byli to Tytus Komornicki, Czesław BorkowskiKorolko, Andrzej Ruszkowski, Maurycy Jaroszyński, Mieczysław Sokołowki, Zdzisław Wojdat. AD PA, sygn. 77 W 36, Le Ministre Secrétaire d'État à l'Intérieur à Monsieur le Gouverneur Général de l'Algérie, à Messieurs les Préfets et Sous-Préfets délégués, Vichy 21 I 1941, b.p. 
Opieki medycznej polskim obywatelom w obozach udzielał dr Tadeusz Schneider. Wizytował on obozy Le Vernet, Gurs i Noé z ramienia PCK (później TOPF) oraz $\mathrm{YMCA}^{75}$. W czasie odwiedzin udzielał pomocy lekarskiej, przywoził niezbędne rzeczy i lekarstwa, interweniował w sprawie polskich obywateli u władz obozowych ${ }^{76}$. Jego akcja zwróciła uwagę Francuzów, został aresztowany, a następnie wywieziony do obozu koncentracyjnego w Dachau, gdzie zmari ${ }^{77}$. Z ramienia YMCA obóz wizytowali również Zdzisław Woydat, Zdzisław Samborski i Bohdan Kularowski ${ }^{78}$.

Na szczególną uwagę zasługuje tutaj działalność na rzecz Polaków podjęta przez Rosę Bailly. W 1919 r. założyła ona stowarzyszenie Les Amis de la Pologne. Energiczna działalność Rosy Bailly pozwoliła skupić wokół stowarzyszenia ważne osoby życia politycznego i kulturalnego Francji ${ }^{79}$.

W czasie wojny stowarzyszenie zaangażowało się w pomoc Polakom internowanym we Francji, współpracowało z PCK we Francji i innymi osobami, którym nie był obojętny los internowanych. Uwięzieni Polacy, zdesperowani tragiczną dla nich sytuacja, pisali już we wrześniu 1939 r. i błagali o pomoc ${ }^{80}$.

75 Jest to międzynarodowa organizacja protestancka o charakterze kulturalno-oświatowym, założona w 1844 r. w Londynie przez George’a Williamsa. Najbardziej znana jest pod nazwą YMCA - Young Men's Christian Association. We Francji i we wszystkich krajach frankofońskich działa od $1850 \mathrm{r}$. W Polsce funkcjonowała od 1923 do 1949 r. Wznowiła swoją działalność w $1990 \mathrm{r}$.

76 AD PA, sygn. 77 W 36, Le Préfet des Basses-Pyrénées à Monsieur le Secrétaire Général de la Police Nationale Direction de l'Administration de la Police 14ème Bureau à Vichy, Pau, 7 VIII 1943, b.p.

77 P. Kalinowski, op. cit., s. 30.

78 AD PA, sygn. 77 W 36, Aides et secours de divers organismes caritatifs; Union chrétienne des jeunes gens de France ou Y.M.C.A.

79 Przewodniczacym Les Amis de la Pologne był Luis Marin, deputowany do Zgromadzenia Narodowego. Ponadto wokół stowarzyszenia skupili się marszałkowie Francji Joseph Joffre, Ferdinand Foch, Philippe Pétain, członek Akademii Francuskiej, późniejszy minister spraw zagranicznych Louis Barthou, generał Maxime Weygand, kardynał Alfred Baudillart, filozof i późniejszy laureat Nagrody Nobla Henri Bergson, profesorowie Collège de France, prefekci, merowie, profesorowie liceów świeckich i zakonnych. M. Pasztor, O polsko-francuskiej wspótpracy kulturalnej i naukowej na prayktadzie dziatalności stowaryyszenia „Les Amis de la Pologne” w latach 1919-1940. CZeść I: lata 1919-1924, „Kwartalnik Historii Nauki i Techniki” 1992, nr 2, s. 177. Więcej o działalności Rosy Bailly pisali, m.in.: M. Pasztor, Un lobby en voie d'affaiblissement. L'activité du groupe franco-polonais à l'assemblée nationale (1921-1936), „Revue d'Histoire Diplomatique" 2000, no 1, s. 53-68; J. Lajarrige, La Pologne d'entre les deux guerres vue par ses amis français. Les Amis de la Pologne: heurts et malheurs de Rosa Bailly, [w:] La presse polonaise en France (Polska prasa we Francji, 1918-1984), textes réunis par D. Beauvois, „Revue du Nord” 1988, no 4, hors-série, Collection Histoire, Université de Lille III, s. 141-150. Obszerna pracę aktywności Rosy Bailly poświęciła Małgorzata Nossowska. Rozprawa oparta jest głównie na materiałach archiwalnych ze spuścizny fundatorki stowarzyszenia przechowywanej w Bibliotece Polskiej w Paryżu. M. Nos sowska, O Francužce, która pokochata Polskę. Rosa Bailly i stowaraysz̨enie Les Amis de la Pologne, Lublin 2012.

80 AAN, Konsulat RP w Tuluzie, sygn. 1364, Mikołaj Samogała do Towarzystwa Przyjaciel [Przyjaciół] Polski w Marseille, Gurs, 20 IX 1939, k. 48-50. 
Rosa Bailly pisała do przedstawicieli władz rządu Vichy w sprawie losu polskich obywateli. Często odwiedzała obozy internowania, kierowała listy otwarte do Polaków. Jej pomoc nie ograniczała się do wsparcia duchowego. Starała się często o pozwolenie na wejście do obozów i odwiedzenie internowanych Polaków, dostarczała niezbędne rzeczy, żywność oraz lekarstwa, zabiegała o ich uwolnienie, starając się dla nich o zatrudnienie w pracach rolnych. Na święta Bożego Narodzenia przygotowywała dla polskich rodzin paczki, w których była odzież, zabawki dla dzieci oraz żywność ${ }^{81}$. Za swoją działalność w niesieniu pomocy otrzymywała wiele listów z podziękowaniami od Polaków, zarówno w języku francuskim, jak i polskim ${ }^{82}$.

Po zakończeniu działań wojennych na terytorium Francji w 1944 r. władze francuskie kolejnymi dekretami zmienily charakter obozów internowania. Decyzją Komisarza Spraw Wewnętrznych Francuskiego Komitetu Wyzwolenia Narodowego, Emmanuela d'Astier de la Vigerie, z 14 marca 1944 r. obozy internowania miały być przeznaczone do internowania osób niebezpiecznych dla państwa francuskiego. Ostatecznie dopiero w październiku prefekci otrzymali wskazówki, że w obozach internowania miały być umieszczane osoby skompromitowane współpraca z rządem Vichy. Od tego momentu m.in. obóz w Gurs oficjalnie otrzymał status „ośrodka pobytu dozorowanego” (centre de séjour surveillé de Gurs - C.S.S. $)^{83}$. Nawet mieszkańcy miasta Béarn rozróżniali w nazewnictwie osoby internowane w czasie wojny od tych internowanych po wojnie. Ci pierwsi byli nazywani Gursiens, a ci drudzy collabos ${ }^{84}$.

Dziś w miejscu obozu Gurs znajduje się mauzoleum z nielicznymi barakami. Zaraz po wojnie większość budynków obozowych została zniszczona albo sprzedana. Pozostawione same sobie zabudowania uległy zniszczeniu. Podobne mauzolea znajdują się w miejscach obozów Le Vernet, Rivesaltes, Les Milles.

Ustawodawstwo francuskie, przyjazne po zakończeniu I wojny światowej wobec cudzoziemców, zaostrzyło się w latach 30. ubiegłego wieku. Sytuacja gospodarcza i rosnące bezrobocie zwiększało jeszcze bardziej nieufność i niechęć do cudzoziemców wśród Francuzów. W okresie kryzysu ekonomicznego rząd francuski zdecydowanie opowiadał się za pierwszeństwem zatrudniania obywateli francuskich. W akcji reemigracyjnej m.in. Polaków władze Francji widziały rozładowanie napiętej sytuacji związanej z bezrobociem w społeczeństwie francuskim, a nakaz ekspulsji administracja francuska wykorzystywała pod byle pretekstem. Niestety działania podejmowane przez polskie władze konsularne nie były w stanie obronić interesów polskiego robotnika przed niesprawiedliwym

\footnotetext{
81 AD PA, sygn. 77 W 36, Aides et secours de divers organismes caritatifs; Groupement d'assistence aux Polonais en France, Croix Rouge polonaise.

82 Spuścizna Marca Montforta, zbiory autorki.

83 Decyzja ta ukazała się w J.O. 29 VIII 1944 r. tuż po upadku reżimu Vichy. C. Laharie, op. cit., s. 266.

84 Ibidem, s. 257.
} 
traktowaniem ze strony rządu francuskiego. Jednak najbardziej jaskrawym przejawem „pozbycia się” obcokrajowców było usankcjonowanie przez rząd francuski w 1938 r. obozów odosobnienia.

Według Denisa Peschanskiego ponad 600 tys. osób ${ }^{85}$ internowano od 1939 do 1945 r. w obozach na terenie Francji. Funkcjonowanie obozów w vichystowskiej Francji miało podobne cele, jak w innych krajach okupowanej Europy: uwięzienie w obozach było pierwszym etapem dyskryminacji Żydów, a następnie ich deportacji do obozów koncentracyjnych i zagłady. Jest prawdą, że w państwie Vichy obozy nie wykorzystywały internowanych do wyniszczających prac fizycznych. Czynnik ekonomiczny miał tutaj marginalną rolę. Internowani we Francji nie byli też poddawani tzw. reedukacji, nie dążono do ich bezwzględnego wyniszczenia fizycznego i psychicznego. Nie zmienia to faktu, że warunki sanitarne w wielu obozach były fatalne. Niektóre z tych na południu Francji zakładane były na terenach gliniastych, a konstruktorzy oraz władze obozów nie przeciwdziałały ich zalaniom przez obfite deszcze, padające szczególnie intensywnie w porze wiosennej (np. w obozie Gurs i Le Vernet), co powodowało, że internowani grzęźli w błocie. Innym przykładem jest obóz Argelès-sur-Mer, założony na plaży Morza Śródziemnego, którego bliskość powodowała duże zawilgocenie baraków. Wielu emigrantów, szukających we Francji lepszych warunków życia niż te, które oferowała im własna ojczyzna, w latach 30. i w czasie wojny spotkał trudny los - zamknięcie w obozach odosobnienia.

\section{Bibliografia}

\section{Źródła archiwalne:}

Archives du Ministère des Affaires étrangères w La Courneuve

Série C, Administrative 1895-1940.

Contrôle des étrangers/service des étrangers 1916-1944.

Archives départementales des Pyrénées-Atlantiques w Pau

Le camp de Gurs.

Sous-Préfecture d'Oloron.

Archives départementales de l'Ariège we Foix

Police politique.

Sûreté nationale.

Archives départementales des Pyrénées-Orientales w Perpignan

Camps d'internement 1939-1943.

85 D. Peschanski, op. cit., s. 475. 


\section{Archives départementales du Pas-de-Calais w Arras-Dainville}

M 3175, Rapatriement de chômeurs.

\section{Archiwum Akt Nowych w Warszawie}

Konsulat RP w Lyonie.

Konsulat RP w Marsylii.

Konsulat RP w Tuluzie.

Konsulat Honorowy RP w Nicei.

Ambasada RP w Paryżu.

\section{Pamiętniki i relacje:}

Dworkin E., Od Manzanares do Oki. Wspomnienia dabrowszczaka, Warszawa 1974.

Olszański T., Życie tułacze, Warszawa 1957.

Taront A., Wspomnienia emigranta polskiego zpótnocnej Francji, do druku przygotowali i komentarzami opatrzyli D. Beauvois, K. Ożóg, J. Śrutek, Wrocław-Warszawa-Kraków 1994.

Zabiełło S., Na posterunku we Francii, Warszawa 1967.

Zaleski-Lubicz Z., Pamiętnik, t. 2: Od Grotowi do Buchenwaldu (1939-1945), oprac., wstęp i przypisami opatrzyła M. Willaume, Paryż-Łódź 1998.

\section{Opracowania:}

Aron R., Histoire de Vichy, Paris 1954.

Azéma J.P., Wieviorka O., Vichy, 1940-1944, Paris 2004.

Becker J.J., Berstein S., Victoire et frustrations, 1914-1929, vol. 12, Paris 1990, Nouvelle bistoire de la France contemporaine.

Biesiekierski M., Polska akcja opiekuńcza we Francji w okresie okupacji niemieckiej (czerwiec 1940 - wrzesień 1944), „Zeszyty Historyczne” (Paryż) 1993, z. 105, s. 38-63.

Cheniaux M. assistée par Joseph Miqueu, Le camp de Gurs (1939-1945). Un ensemble de témoignages dont celui d'Hanna Schramm, 2009.

Dzwonkowski R. SAC, Śladkowski W., Polonia francuska, [w:] Polonia w Europie, red. B. Szydłowska-Cegłowa, Poznań 1992, s. 365-410.

Eisler J., Kolaboracja we Francji, 1940-1944, Warszawa 1989.

Garçon G., Les relations entre l'Union des Associations Catholiques Polonaises et L'Union Centrale des Polonais, 1945-1949, „Revue du Nord” 1992, no 7, hors-série, Collection Histoire, Université de Lille III, s. 35-47.

Gmurczyk-Wrońska M., Polska - niepotrzebny aliant Francij? Francja wobec Polski w latach 1938-1944, Warszawa 2003.

Gogolewski E., Obrona robotników polskich we Francji i zwiazki zawodowe w okresie międrywojennym, [w:] Organizacje polonijne w Europie Zachodniej. Wspótczesność i tradycje. Materialy z. konferencji naukowej w dniach 2 i 3 kwietnia 1987 r. w Poznaniu, red. B. Szydłowska-Cegłowa, J. Kozłowski, Poznań 1991, s. 29-51.

Gogolewski E., Szkolnictwo polskie we Francï (1833-1990), Wrocław 1998.

Gruszyński J., Spoteczność polska we Francji, 1918-1978. Problemy integracyjne trzech pokoleń, Warszawa 1981.

Grynberg A., Les camps du sud de la France : de l'internement à la déportation, „Annales. Économies, Sociétés, Civilisations" 1993, no 3, s. 557-566. 
Indésirables en France 1938-1942. Dossier pédagogique no 7 par S. Orsoni, professeur du Service éducatif des Archives départementales des Bouches-du-Rhône, 2003.

Janowska H., Dwie reemigracje Polaków z. Francji, „Problemy Polonii Zagranicznej” 1964-1965, t. 4, s. 7-26.

Janowska H., Polska emigracja zarobkowa we Francji, 1919-1939, Warszawa 1964.

Jaros S., Reemigracja Polaków z. Francji w latach 1946-1948, „Problemy Polonii Zagranicznej” 1971, t. 6/7, s. 61-95.

Kalinowski P., Emigracja polska we Francji w stų̧bie dla Polski i Francji, 1939-1945, Paryż 1970.

Laharie C., Le camp de Gurs, 1939-1945. Un aspect méconnu de l'bistoire de Vichy, Pau 1993.

Lajarrige J., La Pologne d'entre les deux guerres vue par ses amis français. Les Amis de la Pologne: heurts et malheurs de Rosa Bailly, [w:] La presse polonaise en France (Polska prasa we Francij, 1918-1984), textes réunis par D. Beauvois, „Revue du Nord” 1988, no 4, hors-série, Collection Histoire, Université de Lille III, s. 141-150.

Maj K., Polscy komuniści we Francji, 1919-1946, Warszawa 1971.

Malo E., Le camp de Noé, 1941-1947, Pau 2009.

Markiewicz W., Prz̨eobrażenia świadomości narodowej reemigrantów polskich z. Francji, Poznań 1960.

Michel J., Aux origines de la presse polonaise du Nord-Pas-de-Calais: Le transfert de Westphalie après la Première Guerre mondiale, [w:] La presse polonaise en France (Polska prasa we Francji, 1918-1984), textes réunis par D. Beauvois, „Revue du Nord” 1988, no 4, hors-série, Collection Histoire, Université de Lille III, s. 45-59.

Mond J., Towarzystwo Historyczno-Literackie $i$ Biblioteka Polska w Paryżu. Historia i dzień dzisiejszy, „Nauka Polska” 1991, z. 2, s. 93-116.

Nisiobęcka A., Polacy w obozie Gurs 1939-1945, „Studium Migracyjne - Przegląd Polonijny” 2011, z. 3, s. 9-26.

Nossowska M., O Francuzce, która pokochata Polskę. Rosa Bailly i stowarzyszenie Les Amis de la Pologne, Lublin 2012.

Paczkowski A., Prasa i społecznośćpolska we Francji, 1920-1940, Wrocław-Warszawa-Kraków-Gdańsk 1979.

Pasztor M., O polsko-francuskiej wspólpracy kulturalnej i naukowej na prazykładzie działalności stowarzyszenia „Les Amis de la Pologne” w latach 1919-1940. Czesśc I: Lata 1919-1924, „Kwartalnik Historii Nauki i Techniki" 1992, nr 2, s. 173-192.

Pasztor M., Un lobby en voie d'affaiblissement. L'activité du groupe franco-polonais à l'assemblée nationale (1921-1936), „Revue d'Histoire Diplomatique” 2000, no 1, s. 53-68.

Paxton R. O., La France de Vichy, 1940-1944, Paris 1973.

Peschanski D., La France des camps. L'internement, 1938-1946, Paris 2002.

Ponty J., Dépasser les stéréotypes: au sujet de l'immigration polonaise en France, [w:] La France, la Pologne au-délà des stéréotypes, textes réunis par M. Delaperrière, J. Doberszyc, B. Drwęski, Paris 2004, s. 27-36.

Ponty J., L'immigration dans les textes. France, 1789-2002, Belin-Paris 2004.

Ponty J., Polonais méconnus. Histoire des travailleurs immigrés en France dans l'entre-deux-guerres, Paris 1988.

Weil P., La France et ses étrangers. L'aventure d'une politique de l'immigration de 1938 à nos jours, nouvelle édition refondue, 1991 et 2004.

Zamojski J. E., Polacy w ruchu oporu we Francji, 1940-1945, Wrocław-Warszawa-Kraków-Gdańsk 1975. 